\title{
Prediction of fetal sex in cattle by testosterone levels in allantoic fluid
}

\author{
T. A. Bongso, P. K. Basrur and E. V. YoungLai \\ Department of Biomedical Sciences, University of Guelph, Guelph, Ontario, Canada, N1G 2W2, \\ and Department of Obstetrics and Gynecology, McMaster University Medical Center, Hamilton, \\ Ontario, Canada, L8S $4 J 9$
}

Summary. The testosterone concentration in allantoic fluid between 90 and 150 days
of gestation in cattle can be used to determine the fetal sex; values were $442 \pm 20 \cdot 3$
(S.E.M.) pg testosterone $/ \mathrm{ml}$ for male fetuses and $215 \pm 8 \cdot 2 \mathrm{pg} / \mathrm{ml}$ for female fetuses.

In man, the levels of $17 \beta$-hydroxyandrogens in the amniotic fluid vary according to the sex of the fetus (YoungLai, 1972; Dörner et al., 1973; Giles, Lox, Heine \& Christian, 1974), but chromosomal analysis of abortuses showed that the difference could not be used for accurate prediction of fetal sex (YoungLai \& Lin, 1973). A sex-related difference in the hormone levels of fetal fluid could be of practical use to the livestock industry as an aid to prenatal sex determination and to complement chromosomal analysis of cells in the amniotic fluid (Bongso \& Basrur, 1975).

In the present paper the levels of $17 \beta$-hydroxyandrogens in allantoic and amniotic fluid were measured as testosterone equivalents and related to the sex of the fetus.

The 128 fetal fluid samples (64 amniotic, 64 allantoic) were obtained from cows at various stages of gestation immediately after slaughter at the abattoir. Each sample was centrifuged and the supernatant was stored at $-20^{\circ} \mathrm{C}$ until testosterone levels were measured by radioimmunoassay (YoungLai, 1972). Levels of free testosterone were $<40 \mathrm{pg} / \mathrm{ml}$ in all samples. The antiserum had $35 \%$ cross-reaction with dihydrotestosterone and results are expressed as testosterone equivalents. The coefficient of variation of replicate analysis was about $7 \%$. The crown-rump (C-R) length of each fetus was measured to determine the gestational age (Arthur, 1964), which ranged from 45 to 193 days. The gonadal sex of each well-developed fetus ( $>60$ days) was recorded and the sex of fetuses $<60$ days $(\mathrm{C}-\mathrm{R}=6.4 \mathrm{~cm})$ was confirmed by chromosomal analysis on muscle biopsy cultures.

Table 1. The mean ( \pm S.E.M.) concentrations of testosterone $(\mathrm{pg} / \mathrm{ml})$ in the amniotic and allantoic fluid of bovine fetuses (no. in parenthesis) at different stages of gestation

\begin{tabular}{|c|c|c|c|c|}
\hline \multirow{2}{*}{$\begin{array}{l}\text { Stage of } \\
\text { gestation } \\
\text { (days) }\end{array}$} & \multicolumn{2}{|c|}{ Amniotic fluid } & \multicolumn{2}{|c|}{ Allantoic fluid } \\
\hline & Males & Females & Males & Females \\
\hline$<60$ & $120 \cdot 7 \pm 7 \cdot 2(3)$ & $* 62.0 \pm 6.98$ & $114 \cdot 0 \pm 13 \cdot 3(3)$ & $77 \cdot 5 \pm 8 \cdot 7(4)$ \\
\hline $61-90$ & $155.5 \pm 3.5(2)$ & $111.7 \pm 10.7(3)$ & $190.0 \pm 30.0(2)$ & $129 \cdot 0 \pm 19 \cdot 2(3)$ \\
\hline $91-120$ & $237 \cdot 0 \pm 16 \cdot 1(9)$ & $169 \cdot 6 \pm 16.7(9)$ & $457.8 \pm 32.3(9)$ & $+199 \cdot 0 \pm 11.4(9)$ \\
\hline $121-150$ & $217 \cdot 3 \pm 15 \cdot 5(9)$ & $191.8 \pm 13.7(10)$ & $426 \cdot 7 \pm 27 \cdot 3(9)$ & $\dagger 229.4 \pm 11.4(10)$ \\
\hline $151-180$ & $276.3 \pm 16.3(4)$ & ${ }^{*} 176.2 \pm 13.4(6)$ & $311 \cdot 3 \pm 37 \cdot 7(4)$ & $225.0 \pm 20.9(6)$ \\
\hline $181-210$ & $175.0 \pm 32.9(4)$ & $80(1)$ & $341 \cdot 8 \pm 40 \cdot 1(4)$ & $225(1)$ \\
\hline
\end{tabular}

Significantly different from concentration in males; ${ }^{*} P<0.01 ; \nmid P<0.001$.

Thirty-three of the fetuses were females and 31 were males. The levels of testosterone in amniotic fluid samples did not show any differences between male and female fetuses at the gestational stages examined $(t=1.09 ; P>0.01)$. There was a significant difference between sexes $(t=2.75 ; P<0.01)$ in testosterone levels in allantoic fluids throughout gestation. During the period 91-150 days of gestation (Table 1) testosterone levels were $442 \pm 20 \cdot 3 \mathrm{pg} / \mathrm{ml}$ in males and $215 \pm 8 \cdot 2 \mathrm{pg} / \mathrm{ml}$ in females $(t=3.96$; 
$P<0.001$ ). This period overlaps that which Bongso \& Basrur (1975) found best for aspiration of amniotic fluid for sex prediction. If arbitrary levels of 240 and $320 \mathrm{pg}$ testosterone $/ \mathrm{ml}$ are taken as the limits to predict female and male fetuses respectively, the testosterone concentration of the allantoic fluid alone can be considered indicative of fetal sex. A double-blind study on a number of samples confirmed the validity of this procedure.

The high androgen levels in the allantoic fluid of male fetuses are consistent with the higher serum levels of testosterone and androstenedione found in male fetuses or mothers carrying males (Mongkonpunya, Lin, Noden, Oxender \& Hafs, 1975).

We thank Dr Gordon King, University of Guelph, and J. N. Schneiders Ltd, Kitchener, Ontario, for their help and co-operation in this work, and the National Research Council of Canada and Ontario Ministry of Food and Agriculture for financial support.

\section{References}

ARTHUR, G.H. (1964) Wright's Veterinary Obstetrics. 3rd edn. Baillière, Tindall and Cox, London.

Bongso, T.A. \& Basrur, P.K. (1975) Prenatal diagnosis of sex by amniocentesis. Vet. Rec. 96, 124127.

Dörner, G. von, Stahl, F., Rohde, W., Halle, H., Rossner, W., Grüber, D. \& Herter, U. (1973) Radioimmunologische Bestimmung des Testosterongehalts im Fruchtwasser mannlichen und weiblicher Feten. Endokrinologie 61, 317-320.

Giles, H.R., Lox, C.D., Heine, M.W. \& Christian, C.D. (1974) Intrauterine fetal sex determination by radioimmunoassay of amniotic fluid testosterone. Gynec. Invest. 5, 25, Abstr.

MongkonPunya, K., Lin, Y.C., Noden, P.A., OXender, W.D. \& HaFs, H.D. (1975) Androgens in the bovine fetus and dam. Proc. Soc. exp. Biol. Med. 148, 489-493.

YoungLaI, E.V. (1972) Androgens in human amniotic fluid: relationship to sex of the newborn. $J$. Endocr. 54, 513-514.

YoungLAI, E.V. \& LIN, C.C. (1973) Fetal androgen and human chorionic gonadotropin excretion in relation to genetic sex. Am. J. Obstet. Gynec. 117, 291-292.

Received 1 August 1975 